\title{
Ecobiology Test of Mantangan Species (Merremia peltata (L.) Merr.) from Bukit Barisan Selatan National Park, Lampung
}

\author{
Kurniawati $^{1 *}$, Muhadiono ${ }^{1}$, Iwan Hilwan ${ }^{2}$ \\ ${ }^{1}$ Department of Biology, Faculty of Mathematics and Natural Sciences, Bogor Agricultural University, Bogor \\ 16680, Indonesia \\ ${ }^{2}$ Department of Silviculture, Faculty of Forestry, Bogor Agricultural University, Bogor 16680, Indonesia
}

Article history:

Submission February 2016

Revised March 2016

Accepted February 2017

*Corresponding author:

E-mail: kurniawati_b05@yahoo.com

\begin{abstract}
Mantangan (Merremia peltata (L.) Merr.) is a woody liana. Nowadays, it has become invasive in Bukit Barisan Selatan National Park. The objectives of this research were to analyze: 1) effect of light intensity on the growth of mantangan in the natural and artificial shade, 2) effect of sand addition to the soil media and trimming on the growth rate of mantangan. Forest profile was made at the field in three locations with three light intensity levels: low, moderate, and high. A completely randomized design by three factors: shade, soil media, and trimming were used. Parameters measured were stem length, leaf and buds number, fresh and dry weight. Forest profile analysis showed that high light intensity forest was dominated by mantangan. In contrast, the growth of mantangan was inhibited in low light intensity (75\% shade), with lower dry weight (1.50 g). Soil media and trimming did not affect significantly on the growth of mantangan.
\end{abstract}

Keywords: ACT1 gene, DNA sequence, Benstonea sp., Pandan

\section{Introduction}

Bukit Barisan Selatan National Park (BBSNP) spans in two provinces, started from the southern end of Bengkulu to the tip southern end of Lampung [1]. There are a wide variety of wildlife and plants experience serious threat due to the presence of invasive plant, Merremia peltata a member of the family Convolvulaceae of vines group. $M$. peltata has a yellow or white crown, bellshaped with 5-6 $\mathrm{cm}$ of [2].

$M$. peltata is a liana, has a rapid-expand in the environment that affects to the economy or ecosystem detriment [3]. This plant is spread from Madagascar, Maskarena, Sicilia, the Malay Peninsula, the Philippines, Papua New Guinea, Northern and Southern Australia, and Polynesia [4].

The spread of $M$. peltata is allegedly humanintentions. It is sometimes used as an agriculture ground cover to reduce erosion [5]. In Ambon, its leaves are used for hair washing, cool-head effect and hair loss prevention. Besides, the leaves and the stem-fluids are useful for wound healing [6]. It is potential as a drug, in a study conducted by Alen et al. [7] on male, white mice, $M$. peltata leaf extracts have an anti-cancer activity in reducing micronuclei-cells on femur bone marrow and can increase hematocrit level.

$M$. peltata rapid growth led to natural vegetation disruption in BBSNP conservation area, has invaded more than 7,000 ha [8]. It can diminish the diversity, disturb protected animals, and alter the species composition structure in the natural ecosystem [9]. Its invaded-sites have more open canopy cover and clay soil. Open canopy cover facilitates it to get sunlight, and high clay soil thrives it [10].

Some efforts to control its invasion undertaken by BBSNP, including repeal, spraying, even excavating using heavy equipment. However, it has not succeeded in reducing the invasion [10]. Therefore, it is necessary to do research on more efficient efforts to break the M. peltata life cycle. This study aimed to analyze the effect of the intensity of natural and artificial sunlight, analyze the effect 
of sand administration into growing media and the influence of stem pruning on its growth.

Four degenerate actin primers have been designed based on actin gene conserved regions among the known plant, animal, fungal, and protist, namely PlAc12S and PlAc46S-20 as forward primers and PlAc245N-20 and PlAc284N as reverse primers [6]. The four primers have been applied in Melastoma malabathricum [5]. A primer pair of PlAc12S-20 and PlAc245N-20 has also been used to isolate $E$. floribundus actin gene [13]. Furthermore, a primer pair of PlAc46S-20 and PlAc245N-20 has been used to isolate durik-durik (Syzygium sp.) actin gene [14]. However, DNA sequence of actin gene on Benstonea sp. clone Riau and also on other species in Pandanaceae family has never been reported. Therefore, this study aims to isolate the DNA sequence encoding actin from Benstonea sp. clone Riau.

\section{Material and Methods \\ Time and locations}

Field data retrieval was conducted in May 2014 for ten days at three sites of BBSNP that is included in the Tampang Resort, Pematang District, Tanggamus Regency, Lampung. The experiments of the effects of shade, growing media, and pruning were started from February to June 2015 in the experimental garden of Forestry Research and Development Institute (LITBANGHUT) Gunung Batu, Bogor.

\section{Forest profile establishment for dominance}

Forest profile was established at three sites, namely low light forest (LLF) with the light intensity range of $10-30 \%$, moderate light forest (MLF) with the light intensity range of $35-60 \%$, and highlight forests (HLF) with the light intensity range of $65-100 \%$. Each location is placed a plot with the size of $20 \times 20 \mathrm{~m}^{2}$. The tree position against $\mathrm{X}$ and $\mathrm{Y}$ axis was determined. The tree height, chest height diameter, and first branch height were measured. The tree architecture was drawn to scale on graph paper. The mapping of canopy projection to the ground was done. The canopy cover area was calculated.

\section{Merremia peltata biomass}

M. peltata wet weight in the field was measured using the plots of $1 \times 1 \mathrm{~m}^{2}$. The sites were performed for three treatment replicates. M. pel- tata was lifted to the root, and the wet weight was measured.

\section{Merremia peltata growth response measurement}

Experiments was performed by a completely randomized design of factorial (RAL Factorial) with three factors: shade $(0 \%, 50 \%$, and $75 \%)$, growing media (soil and soil with sand mixture of $30 \%)$ and pruning (pruned and not pruned). Each treatment was performed three replicates.

The cuts of $M$. peltata stem were maintained on polythene bags, sized $30 \times 25 \mathrm{~cm}^{2}$ using the soil and soil with sand mixture of $30 \%$. The sand was obtained from Dramaga Research Forest, Situ Gede subdistrict, Bubulak village, West Bogor district, Bogor. The 15-cm stem cuts, using M. peltata obtained from LITBANGHUT Gunung Batu, Bogor. $M$. peltata was smeared by Rotton F growth regulators as a root growth trigger. M. peltata stem was pruned $20 \mathrm{~cm}$ from the shoots at a 1-month age after planting to observe the shoots growth and shade treatment given for the light influence was performed by black shading-net installment. M. peltata was harvested at 90 days after treatment. The stem height, number of leaves, number of shoots, wet weight, and dry weight were measured. M. peltata roasted at a $70^{\circ} \mathrm{C}$ temperature to obtain a constant dry weight.

\section{Data analysis}

The cover of forest profile canopy was analyzed using the formula:

Note:

cp : Crown Percentage

d : Diameter

Stem height, the number of leaves, the number of shoots, wet weight and dry weight, were analyzed using Analysis of Variance (ANOVA) and advance-analyzed using Duncan's test Multiple Range Test (DMRT) at a test level of 95\%. Data analysis was performed using SPSS version 22.

\section{Results and Discussion Dominance}

The dominant species in LLF based on the forest profile was Hopea dryobalanoides with canopy cover area of $14.92 \%$ (Table 1 ). There could be easy-found the category of the existing tree, fu- 
Table 1. Data diagram profile low-light forest (LLF)

\begin{tabular}{|c|c|c|c|c|}
\hline No. & Species & Crown position & Habit & Canopy Cover (\%) \\
\hline 1. & Glochidion obscurum & $\mathrm{B}$ & Pole & 2.25 \\
\hline 2. & Koilodepas brevipes & $\mathrm{C}$ & Stake & 0.81 \\
\hline 3. & Chisocheton ceramicus & $\mathrm{C}$ & Stake & 0.56 \\
\hline 4. & Pterospermum javanicum & B & Pole & 2.72 \\
\hline 5. & Shorea javanica & B & Pole & 1.44 \\
\hline 6. & Hopea sangal & A & Tree & 4.20 \\
\hline 7. & Koilodepas brevipes & $\mathrm{C}$ & Stake & 0.72 \\
\hline 8. & Glochidion obscurum & $\mathrm{C}$ & Stake & 1.21 \\
\hline 9. & Glochidion obscurum & $\mathrm{C}$ & Stake & 0.42 \\
\hline 10. & Pterospermum javanicum & $\mathrm{C}$ & Stake & 0.90 \\
\hline 11. & Hopea sangal & $\mathrm{C}$ & Stake & 0.42 \\
\hline 12. & Koilodepas brevipes & A & Tree & 5.06 \\
\hline 13. & Glochidion obscurum & A & Tree & 5.06 \\
\hline 14. & Pseudovaria reticulata & B & Pole & 2.89 \\
\hline 15. & Macaranga sp. & $\mathrm{C}$ & Stake & 0.72 \\
\hline 16. & Macaranga sp. & A & Tree & 3.61 \\
\hline 17. & Hopea sangal & $\mathrm{C}$ & Stake & 0.56 \\
\hline 18. & Diospyros daemona & A & Tree & 5.29 \\
\hline 19. & Hopea dryobalanoides & $\mathrm{C}$ & Stake & 0.30 \\
\hline 20. & Clerodendron laevifolium & $\mathrm{C}$ & Stake & 0.49 \\
\hline 21. & Hopea dryobalanoides & B & Pole & 2.40 \\
\hline 22. & Hopea dryobalanoides & A & Tree & 3.80 \\
\hline 23. & Goniothalamus sumatranus & A & Tree & 5.29 \\
\hline 24. & Cissus sp. & $\mathrm{C}$ & Stake & 0.90 \\
\hline 25. & Shorea javanica & A & Tree & 3.06 \\
\hline 26. & Macaranga sp. & A & Tree & 3.80 \\
\hline 27. & Macaranga sp. & A & Tree & 6.25 \\
\hline 28. & Hopea dryobalanoides & A & Tree & 4.62 \\
\hline 29. & Clerodendron laevifolium & A & Tree & 5.29 \\
\hline 30. & Cissus sp. & A & Tree & 3.42 \\
\hline 31. & Hopea dryobalanoides & A & Tree & 3.80 \\
\hline 32. & Shorea javanica & $\mathrm{C}$ & Stake & 1.00 \\
\hline \multirow[t]{2}{*}{33.} & Goniothalamus sumatranus & $\mathrm{B}$ & Pole & 2.40 \\
\hline & Total & & & $85.66 \%$ \\
\hline
\end{tabular}

ture tree, and past tree. It had a maximum canopy height at layer A (30 m height or above). The LLF profile showed the forest would continue to grow, many trees with maximum canopy height in A layer are still in layer B and C. It showed the canopy layer would continue to grow and move up the tree size increasing. $M$. peltata was allegedly not able to occupy this forest because of forming a dense that light was difficult to penetrate the forest ground.

Goniothalamus sumatranus dominated MLF with a total canopy cover of $7.56 \%$. There could be found the category of the present tree and future tree, with a canopy height of A layer, and some are still in B layer $(20-30 \mathrm{~m})$ and $\mathrm{C}(4-20 \mathrm{~m})$. Stakes were easy-found than trees and poles, not dissimilar to LLF, also dominated by a high tree canopy with a maximum in A layer (Table 2). Codominant trees (future tree) were prevalent in LLF and MLF. The young trees have the ability to grow, making the forest condition is getting better, with a dense canopy cover that make $M$. peltata unable to survive.

HLF did not have a lot of trees; the forest canopy openness caused $M$. peltata domination. There were 11 individuals from species of future trees; canopy height was still in B and C layer (Table 3 ). The presence of $M$. peltata could change the ground temperature, with adense-leaves cover led to the ground temperature change.

The dense-leaves cover of $M$. peltata covered the forest ground, so the seedling phase and undergrowth under the auspices of $M$. peltata, did not get sunlight. Many trees found twist-died and covered by $M$. peltata, unable to get sunlight. It is feared to reduce the diversity in BBSNP. 
Table 2. Data diagram profile moderate-light forest (MLF)

\begin{tabular}{|c|c|c|c|c|}
\hline No. & Species & Crown position & Habit & Canopy Cover (\%) \\
\hline 1. & Diospyros korthalsiana & $\mathrm{C}$ & Stake & 0.64 \\
\hline 2. & Diospyros korthalsiana & $\mathrm{C}$ & Stake & 0.58 \\
\hline 3. & Goniothalamus sumatranus & B & Pole & 2.72 \\
\hline 4. & Diospyros korthalsiana & A & Tree & 5.52 \\
\hline 5. & Goniothalamus sumatranus & A & Tree & 4.84 \\
\hline 6. & Koilodepas brevipes & $\mathrm{C}$ & Stake & 1.56 \\
\hline 7. & Cissus sp. & $\mathrm{C}$ & Stake & 0.30 \\
\hline 8. & Dillenia excelsa & A & Tree & 3.42 \\
\hline 9. & Dillenia excelsa & $\mathrm{C}$ & Stake & 0.81 \\
\hline 10. & Glochidion obscurum & $\mathrm{C}$ & Stake & 0.30 \\
\hline 11. & Koilodepas brevipes & $\mathrm{C}$ & Stake & 1.32 \\
\hline 12. & Dillenia excelsa & $\mathrm{C}$ & Stake & 0.49 \\
\hline 13. & Popowia bancana & $\mathrm{C}$ & Stake & 1.32 \\
\hline 14. & Popowia bancana & A & Tree & 3.42 \\
\hline 15. & Glochidion obscurum & A & Tree & 3.42 \\
\hline 16. & Dracontomelon dao & A & Tree & 3.61 \\
\hline 17. & Dracontomelon dao & $\mathrm{C}$ & Stake & 0.58 \\
\hline 18. & Pterospermum javanicum & A & Tree & 3.42 \\
\hline 19. & Pterospermum javanicum & $\mathrm{C}$ & Stake & 0.58 \\
\hline 20. & Diospyros daemona & $\mathrm{C}$ & Stake & 0.56 \\
\hline 21. & Diospyros daemona & $\mathrm{C}$ & Stake & 0.81 \\
\hline 22. & Dyera castulata & $\mathrm{C}$ & Stake & 1.00 \\
\hline 23. & Dyera castulata & $\mathrm{C}$ & Stake & 1.32 \\
\hline 24. & Rinorea lanceolata & A & Tree & 3.24 \\
\hline 25. & Dyera castulata & $\mathrm{C}$ & Stake & 1.44 \\
\hline 26. & Ormosia sumatrana & $\mathrm{A}$ & Stake & 3.24 \\
\hline 27. & Rinorea lanceolata & $\mathrm{C}$ & Stake & 0.81 \\
\hline 28. & Dyera castulata & $\mathrm{C}$ & Stake & 1.69 \\
\hline 29. & Dracontomelon dao & $\mathrm{C}$ & Stake & 0.30 \\
\hline
\end{tabular}

\section{Merremia peltata biomass}

Related to the canopy cover of each location, the wet weight measures of M. peltata in MLF and LLF showed a not significant-difference. $M$. peltata was not able to survive in a state of shade, so it was rarely found in the woods. HLF (invaded forest) with a canopy cover of $15.57 \%$ had a wet weight of $M$. peltata 50-times greater than in LLF with a canopy cover of $85.66 \%$ and 7 -times greater than in MLF with 53.84\% canopy cover (Figure 1). This is consistent with the research in experimental garden, $0 \%$ shade or no shading-net produced the higher level of wet weight than $50 \%$ and $75 \%$ shade.

The high-wet weight of M. peltata in HLF is caused by its ability to use sunlight as well to increase in weight. Instead the low wet weight in LLF, due to the high-shade resulted in depressed and lo-wet weight. The high shade could reduce the main photosynthesis-active radiation on resulting a decrease in net assimilation [11]. Plants with low-light resulting in plant stems tend to be small, due to the underdeveloped xylem caused by stem cells enlargement was inhibited, resulting in the low-weight [12]. Shortage of sunlight can reduce photosynthate stored in organs [13], resulting in wet-weight decreased.

M. peltata is likely to extend its dominance over the region in the broader open land of BBSNP. Increasing the canopy density with tree vegetation could be one of the alternatives suggested controlling M. peltata. Pro-pagation of native tree species planting and proper spacing could produce a dense canopy cover. Limited sunlight reaching the ground is expected to reduce the population and prevent domination of $M$. peltata. The high-light intensity affected by the auxin activity in apical meristem. The higher light intensity, the higher auxin activity, resulting in well-developed [14], similar to wet weight will increase with shoots increase. The increase in growth rate coupled with an increase in solar radiation will affect 
Table 3. Data diagram profile high light forest (HLF)

\begin{tabular}{llclc}
\hline No & Species & Crown position & Habit & Canopy cover (\%) \\
\hline 1 & Koilodepas brevipes & B & Pole & $2.10 \%$ \\
2 & Canarium denticulatum & C & Stake & $0.25 \%$ \\
3 & Nauclea officinalis & C & Stake & $0.25 \%$ \\
4 & Koilodepas brevipes & A & Tree & $3.24 \%$ \\
5 & Glochidion obscurum & C & Stake & $0.20 \%$ \\
6 & Croton argyratus & C & Stake & $1.10 \%$ \\
7 & Canarium denticulatum & C & Stake & $0.56 \%$ \\
8 & Glochidion arborescens & B & Pole & $2.25 \%$ \\
9 & Glochidion obscurum & C & Stake & $1.21 \%$ \\
10 & Glochidion arborescens & B & Pole & $2.72 \%$ \\
11 & Nauclea officinalis & C & Stake & $1.69 \%$ \\
\hline \multicolumn{2}{l}{ Total } & & & $15.57 \%$ \\
\hline
\end{tabular}

\section{Note:}

Description crown position based on layer [26]:

$\mathrm{A} \quad=$ trees with a height of $30 \mathrm{~m}$ and above (trees present, including past tree)

$\mathrm{B}=$ tree with a height of $20-30 \mathrm{~m}$ (tree future)

$\mathrm{C}=$ tree with a height of $4-20 \mathrm{~m}$ (tree future)

Table 4. Summary of multivariate real effect of shade, growing media, pruning and its interaction with the invasive plant growth

\begin{tabular}{|c|c|c|c|c|c|c|c|c|}
\hline \multirow[t]{2}{*}{ Treatment } & \multicolumn{8}{|c|}{ Parameter } \\
\hline & $\mathrm{df}$ & $\begin{array}{l}\text { Stem- } \\
\text { height }\end{array}$ & $\begin{array}{l}\text { Number } \\
\text { leaves }\end{array}$ & of & $\begin{array}{l}\text { Number } \\
\text { shoots }\end{array}$ & of & $\begin{array}{l}\text { Wet } \\
\text { weight }\end{array}$ & Dry weight \\
\hline Shade & 2 & $<0.000$ & $<0.000$ & & $<\mathbf{0 . 0 0 0}$ & & $<0.000$ & $<\mathbf{0 . 0 0 0}$ \\
\hline Growing media & 1 & 0.177 & 0.091 & & 0.061 & & 0.062 & 0.181 \\
\hline Pruning & 1 & 0.166 & 0.318 & & 0.331 & & 0.538 & 0.693 \\
\hline Shade* Growing media & 2 & 0.419 & 0.425 & & 0.501 & & 0.803 & 0.220 \\
\hline Shade*Pruning & 2 & 0.491 & 0.278 & & 0.670 & & 0.805 & 0.874 \\
\hline Growing media *Pruning & 1 & 0.505 & 0.973 & & 0.743 & & 0.849 & 0.431 \\
\hline $\begin{array}{l}\text { Shade* Growing media } \\
\text { *Pruning }\end{array}$ & 2 & 0.545 & 0.542 & & 0.747 & & 0.619 & 0.416 \\
\hline
\end{tabular}

Note: df: degrees of freedom; bold indicate significant differences at $\mathrm{p}<0.05$

linearly on biomass [15].

\section{Merremia peltata growth}

M. peltata growth was affected by the sunlight intensity (Table 4). The shade $0 \%$ had the highest plant height, number of leaves and shoots, wet weight and dry weight (Figure 2). The quality of light is important in the reproductive organs of vegetative propagation. Differences in the ability of plants to use environmental factors such as water, $\mathrm{CO}_{2}$, temperature, solar energy, and so affect the photosynthesis performance [16]. These factors affect the growth, especially shoots. Reduction of light causes the imperfect development of the plant [17].

Parameters plant height, the number of leaves, wet weight and dry weight on shade $50 \%$ had no significant effect with shade $0 \%$. Shade $50 \%$ did not affect to the growth inhibition. As a fast- growth species, these plants quickly dominated the open land and formed a dense population. The forest clearing provided full of the sun, favorite of pioneer species [18]. The growth was stalled on shade $75 \%$, indicated that the forest clearing supports its development. The lack of light affected by the absence of photosynthesis led to the decomposition of photosynthesis products for respiration, reduced the food reserves and stunted the plant growth [13].

The difference in shade level affected to light intensity, temperature, and humidity. The light intensity received by plants affected by the light energy availability converted into thermal and chemical energy. The greater the shade (the smaller the light intensity received by the plant), the lower air temperature and the higher air humidity. The lower and upper air humidity inhibited the plant growth [19]. 


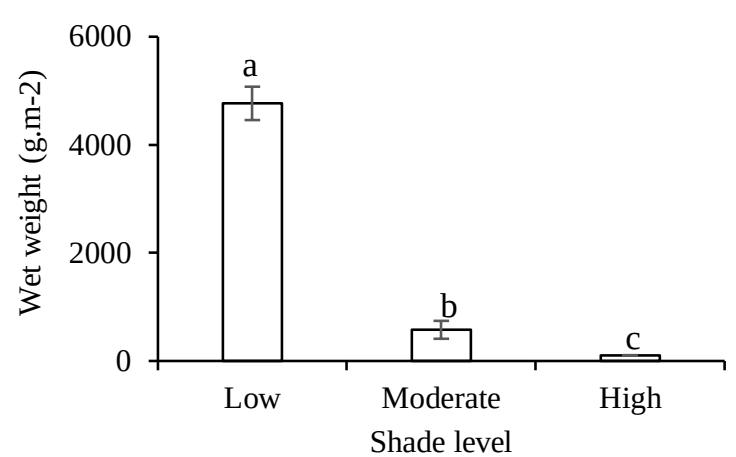

Figure 1. The weight of wet $M$. peltata in three research sites in BBSNP. The data show the average value \pm SE. Different letters indicate significant differences between the of shade by Duncan test at $\mathrm{p}<0.05$

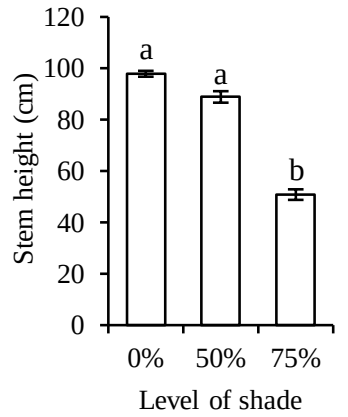

(a)

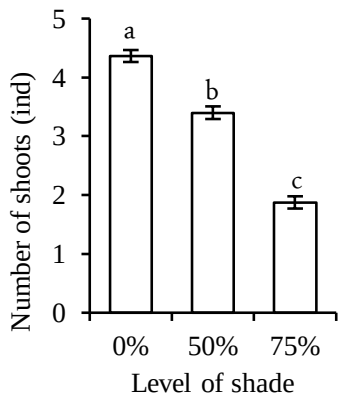

(c)

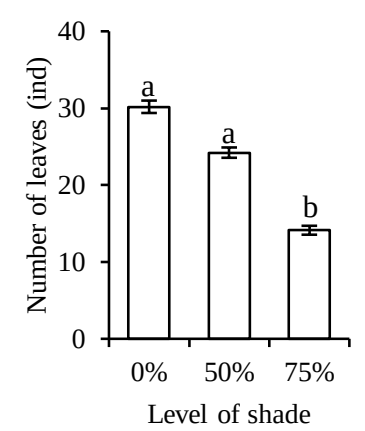

(b)

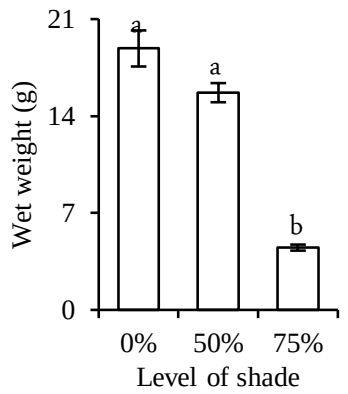

(d)

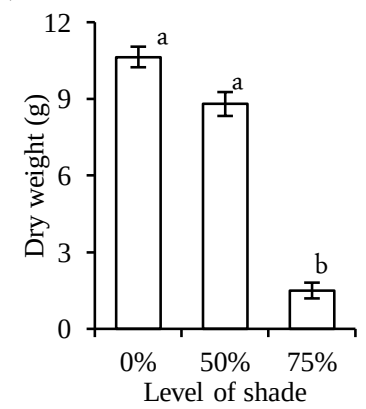

(e)

Figure 2. Effect of shade treatment is low (0\%), moderate (50\%) and high (75\%) to the growth of the invasive plant. Different letters indicate significant differences between the shade by Duncan test at $\mathrm{p}<0.05$
The inhibition of growth on shade $75 \%$ were related to the environmental factors received by the plant. It had a high-humidity so that $M$. peltata could not survive, even many of dead. The effect of low-light intensity on various commodities are widely reported. The high-shade on sensitive genotype rice caused the number of grains/small panicles and percentage of empty grain is high, affected to the low-seed production [20]. The low light intensity was lowering the yield of soybean [21], corn [22], upland rice [23], sweet potato [24], and taro [25].

The growth medium and stem pruning factors did not show a significant effect of the parameter measured. The stem pruning did not affect the shoots growth. It is thought to the $M$. peltata growth be influenced by the shade, so the dense shade (75\%) inhibits the shoots growth although the stems trimmed. Pruning was done to affect the production of the axillar-rod shoot in addition to other important factors such as environmental conditions (moisture, nutrients and sunlight exposure). It aimed to the $M$. peltata control conducted by pulling down to the roots, not pruning. The rest of $M$. peltata roots or stems left in the soil was able to bring out new shoots.

The interaction of shade and growing medium, shade and pruning, growing medium and pruning, and interaction between the three treatments have no significant effect on the measured parameters. The sunlight intensity is a fundamental element of M. peltata growth to become invasive.

\section{Conclusion}

The result of observation in the field concluded that HLF with a canopy cover of $15.57 \%$ is dominated by $M$. peltata, evidenced by high-wet weight of $M$. peltata in this forest compared to low-light forests (LLF) and moderate-light forest (MLF). Based on the results in experimental garden, growth parameters of plant height, the number of leaves, the number of shoots, wet-weight and dried-weight on $M$. peltata of $75 \%$ shade is the lowest compared to $0 \%$ shade and 50\% shade. Growing medium and pruning does not show a significant effect on $M$. peltata growth.

\section{Acknowledgment}

I would like to acknowledge the support of the Director General of Higher Education on granting scholarship of Beasiswa Program Pascasarjama 
Da-lam Negeri (BPPDN), the BBSNP, the Conservation and Rehabilitation Research and Development Centre (Puskonser) Forestry Research and Development Institute (LITBANGHUT) of Gunung Batu Bogor for providing a research-base, Laboratory of Ecology of Mathematic and Natural Science Faculty (FMIPA) of IPB for the research facilities, and FORIS-Indonesia for the research funding.

\section{References}

1. Gaveau DLA, Wandono H, Setiabudi F (2007) Three decades of deforestation in South West Sumatera: Have protected areas halted forest loss and logging, and promoted re-growth. Biology Conservation 134 (4): 495 - 504. doi: 10.1016/j.biocon.2006.08.035.

2. Fosberg FR, Sachet MH (1977) Flora of Micronesia, 3: Convolvulaceae. Washington DC, Smithsonian Institution Press. doi: 10.5479/si.0081024X.36.

3. Wittenberg R, Cock MJW (2001) Invasive alien species: A toolkit of best prevention and management practices. Oxon, CABI Publisher.

4. Oostroom VSJ, Hoogland RD (1953) Convolvulaceae. In: van Steenis GCCJ, Holttum RE. Flora Malesiana 14. Boston, Hague. pp $452-455$.

5. Kirkham WS (2005) Valuing invasives: Understanding the Merremia peltata invasion in Post-Colonial Samoa. Doctoral Thesis. University of Texas.

6. Heyne K (1987) Tumbuhan berguna Indonesia III. Raja Jakarta, Grafindo Persada.

7. Alen Y, Suhatri, Selawati R (2009) Uji efek anti kanker ekstrak etanol daun “Aka Lambuang” (Merremia peltata (L.) Merr.) pada mencit putih jantan dengan metoda micronucleus assay. Farmasi 14 (1): 141 - 147

8. Master J, Tjitrosoedirdjo SS, Qayim I (2013) Ecological impact of Merremia peltata (L.) Merrill invasion on plant diversity at Bukit Barisan Selatan National Park. Biotropia 20 (1): 29 - 37. doi: 10.11598/btb.2013.20.1.294.

9. Mardiati Y (2014) Karakter fisiologi Merremia peltata (L.) Merrill asal Taman Nasional Bukit Barisan Selatan Lampung. Master Thesis. Departement of Biology. Bogor Agricultural University.

10. Master J (2012) Invasi Merremia peltata (L.) Merrill dan dampaknya terhadap keanekaragaman tumbuhan di Taman Nasional
Bukit Barisan Selatan. Master Thesis. Departement of Biology. Bogor Agricultural University.

11. Lambers H, Chapin FS, Pons TL (1998) Plant physiologycal ecology. New York, Springer Verlag.

12. Wirnas D (2005) Analisis kualitatif dan molekular dalam rangka mempercepat perakitan varietas baru kedelai toleran terhadap intensitas cahaya rendah. Master Thesis. Faculty of Agriculture. Bogor Agricultural University.

13. Schaffer AA (1996) Photoassimilate distribution in plant and crops. New York, Marcel Dekker.

14. Widiastoety D, Prasetyo W, Salvania N (2000) Pengaruh naungan terhadap produksi tiga kultivar bunga anggrek Dendrobium. Jurnal Hortikultura 9 (4): 302 - 306.

15. Salisburry FB, Ros CW (1995) Fisiologi tumbuhan jilid 1. Bandung, Bandung Institute of Technology.

16. Heddy S (2002) Metode analisis vegetasi dan komunitas. Jakarta, Raja Grafindo Persada.

17. Sastroutomo S (1990) Ekologi gulma. Jakarta, Gramedia Pustaka Utama.

18. Whitmore TC (1989) Canopy gaps and the two major groups of forest trees. Ecology 70: 536 - 538.

19. Kramer PJ, Kozlowski TT (1979) Physiology of woody plants. New York, Academic Press.

20. Sopandie D, Chozin MA, Sastrosumarjo S et al. (2003) Toleransi padi gogo terhadap naungan. Hayati 10 (2): 71 - 75.

21. Asadi D, Arsyad M, Zahara H, Darmijati (1997) Pemuliaan kedelai untuk toleran naungan dan tumpangsari. Buletin Agrobio 1 (2): $15-20$.

22. Andrade FH, Uhart SH, Frugone MI (1993) Intercepted radiation at flowering and kernel number in maize: Shade versus plant density effects. Crop Science 33 (3): 482 - 485. doi:10.2135/cropsci1993.0011183X003300030013x.

23. Supriyono B, Chozin MA, Soepandie D, Darusman LK (2000) Perimbangan pati sukrosa dan aktivitas enzim sukrosa fosfat sintase pada padi gogo yang toleran dan peka terhadap naungan. Hayati 7 (2): 31 - 34 .

24. Nurhayati AP, Lontoh, Koswara J (1985) Pengaruh intensitas dan saat pemberian naungan terhadap produksi ubi jalar (Ipomoea batatas (L.) Lmp.) Buletin Agrikultur 16 (1): 28 - 38.

25. Wirawati TBS, Purwoko D, Sopandie I, Hanarida. (2002) Studi fisiologi adaptasi talas terhadap kondisi naungan. Master Thesis. Bogor Agricultural University.

26. Soerianegara I, Indrawan A (2005) Ekologi Hutan Indonesia. Bogor, Bogor Agricultural University. 
This page is intentionally left blank. 